\title{
Applying a framework for landscape planning under climate change for the conservation of biodiversity in the Finnish boreal forest
}

Mazziotta, Adriano; Triviño, Maria; Tikkanen, Olli Pekka; Kouki, Jari; Strandman, Harri;

Mönkkönen, Mikko

Published in:

Global Change Biology

DOI:

$10.1111 / \mathrm{gcb} .12677$

Publication date:

2015

Document version

Peer reviewed version

Citation for published version (APA):

Mazziotta, A., Triviño, M., Tikkanen, O. P., Kouki, J., Strandman, H., \& Mönkkönen, M. (2015). Applying a framework for landscape planning under climate change for the conservation of biodiversity in the Finnish boreal forest. Global Change Biology, 21(2), 637-651. https://doi.org/10.1111/gcb.12677 
Received Date : 10-May-2014

Accepted Date : 11-Jun-2014

Article type : Primary Research Articles

\title{
Applying a framework for landscape planning under climate change for the conservation of biodiversity in the Finnish boreal forest
}

Running head: Conservation planning under climate change

Authors: Adriano Mazziotta ${ }^{1 *}$, Maria Triviño ${ }^{1}$, Olli-Pekka Tikkanen ${ }^{2,3}$, Jari Kouki ${ }^{3}$, Harri Strandman $^{3}$, Mikko Mönkkönen ${ }^{1}$

\author{
Affiliations: \\ ${ }^{1}$ Department of Biological and Environmental Science, P.O. Box 35, 40014 University of \\ Jyväskylä, Finland \\ ${ }^{2}$ Finnish Forest Research Institute, Joensuu Unit, P.O. Box 68, FI-80101 Joensuu, Finland \\ ${ }^{3}$ School of Forest Sciences, University of Eastern Finland, P.O. Box 111, FI-80101 Joensuu, \\ Finland
}

*Corresponding author: Tel.: +358-40-373-1001, Fax: +358-14-617-239, E-mail: adriano.mazziotta@jyu.fi

This article has been accepted for publication and undergone full peer review but has not been through the copyediting, typesetting, pagination and proofreading process, which may lead to differences between this version and the Version of Record. Please cite this article as doi: $10.1111 /$ gcb. 12677

This article is protected by copyright. All rights reserved. 
Keywords: systematic conservation planning, climate change adaptation, landscape conservation capacity, climate vulnerability, forest ecosystem model, forest gap model, woody debris, conservation strategy, forest management, emission scenarios

\title{
Type of Paper: Primary Research Article
}

\begin{abstract}
Conservation strategies are often established without consideration of the impact of climate change. However, this impact is expected to threaten species and ecosystem persistence and to have dramatic effects towards the end of the $21^{\text {st }}$ century. Landscape suitability for species under climate change is determined by several interacting factors including dispersal and human land use. Designing effective conservation strategies at regional scales to improve landscape suitability requires measuring the vulnerabilities of specific regions to climate change and determining their conservation capacities. Although methods for defining vulnerability categories are available, methods for doing this in a systematic, cost-effective way have not been identified. Here, we use an ecosystem model to define the potential resilience of the Finnish forest landscape by relating its current conservation capacity to its vulnerability to climate change. In applying this framework, we take into account the responses to climate change of a broad range of red-listed species with different niche requirements. This framework allowed us to identify four categories in which representation in the landscape varies among three IPCC emission scenarios (B1,low-; A1B,intermediate-; A2,high-emissions): a) susceptible ( $\mathrm{B} 1=24.7 \%, \mathrm{~A} 1 \mathrm{~B}=26.4 \%, \mathrm{~A} 2=26.2 \%)$, the most intact forest landscapes vulnerable to climate change, requiring management for heterogeneity and resilience; $b)$ resilient $(\mathrm{B} 1=2.2 \%, \mathrm{~A} 1 \mathrm{~B}=0.5 \%, \mathrm{~A} 2=0.6 \%)$, intact areas with low vulnerability
\end{abstract}

This article is protected by copyright. All rights reserved. 
that represent potential climate refugia and require conservation capacity maintenance; c) resistant $(\mathrm{B} 1=6.7 \%, \mathrm{~A} 1 \mathrm{~B}=0.8 \%, \mathrm{~A} 2=1.1 \%)$, landscapes with low current conservation capacity and low vulnerability that are suitable for restoration projects; d) sensitive $(\mathrm{B} 1=66.4 \%, \mathrm{~A} 1 \mathrm{~B}=72.3 \%, \mathrm{~A} 2=72.0 \%)$, low conservation capacity landscapes that are vulnerable and for which alternative conservation measures are required depending on the intensity of climate change. Our results indicate that the Finnish landscape is likely to be dominated by a very high proportion of sensitive and susceptible forest patches, thereby increasing uncertainty for landscape managers in the choice of conservation strategies.

\section{Introduction}

There is strong evidence that human-induced climate change is modifying landscapes in many different ways (e.g., Cramer et al., 2001, Walther et al., 2002; Schmitz et al., 2003; Walther et al., 2005; Thuiller, 2007), with effects on inhabiting species; in fact, climate change is expected to become a major threat to biodiversity in the $21^{\text {st }}$ century (e.g., Dawson et al., 2011; Bellard et al., 2012, Mantyka-Pringle et al., 2012). However, considerable uncertainty remains regarding how landscapes can be systematically and effectively managed to minimise the loss of biological diversity. Among the most cited recommendations are increasing landscape connectivity by designing corridors, removing barriers for dispersal, placing reserves close to each other and/or improving the quality of the matrix habitat (Heller \& Zavaleta, 2009). To minimise the negative impact of climate change, managers of natural resources are expected to follow the directives of the Convention on Biological Diversity (2010) and to offer a portfolio of adaptation measures based on scientific knowledge and ranging from risk-adverse to risk-tolerant (Heller \& Zavaleta, 2009; Klausmeyer et al., 2011;

Crossman et al., 2012; Oliver et al., 2012; Summers et al., 2012).

This article is protected by copyright. All rights reserved. 
Gilsson et al. (2013) suggest that the choice of conservation strategy should rely on assessment both of a landscape's conservation capacity (i.e., its resilience to change) and of its vulnerability to climate change (i.e., its sensitivity and exposure sensu Dawson et al. 2011). Landscape conservation capacity can be defined as the ability of a landscape to maintain habitats for species populations and their spatial configuration (connectivity), both of which are essential for species persistence (metapopulation viability, Hanski \& Ovaskainen, 2000). In Dawson et al. (2011), climate vulnerability is defined as the extent to which a species or population is threatened with decline, reduced fitness, genetic loss, or extinction due to climate change. In a landscape context, Gilsson et al. (2013) defined climate vulnerability as vulnerability that depends on modifications of the landscape induced by climate change (exposure) and on how species respond to these changes (sensitivity that is dependent on topographic relief). Using this framework, we can assess whether landscapes provide suitable habitats for species under new climatic conditions. Categorising landscapes in the two-dimensional space of conservation capacity and climatic vulnerability would greatly help in assigning them to relevant conservation actions (Heller \& Zavaleta, 2009).

A recent study by Watson et al. (2013) noted three shortcomings that are often found when conservation-oriented climate change assessments are applied. These are: (1) failure to consider the ecosystem's response as a whole while considering only species-specific responses, leading to a lack of practical applications; (2) lack of spatial representation of the categories; (3) assessing vulnerability by taking into account the system's exposure to climate change while failing to consider the two other components of vulnerability (adaptive capacity and sensitivity). To overcome these shortcomings, Watson et al. (2013) proposed a framework for categorisation of the world's ecoregions based on their intactness (i.e.,

This article is protected by copyright. All rights reserved. 
conservation capacity) and future climate stability (i.e., climate vulnerability) when proposing conservation strategies under climate change.

Downscaling of this approach is needed to make it applicable to landscape planning under climate change (Heller \& Zavaleta, 2009; Klausmeyer et al., 2011; Summers et al., 2012). Nevertheless, calculation of the two abovementioned indicators, conservation capacity and climate vulnerability, at a fine scale for the total biodiversity in the landscape is very challenging. In fact, estimation of the landscape conservation capacity requires calculating the conservation capacity of the elements of the landscape relevant to the persistence of species. Species distribution models are commonly used to estimate future shifts in climatic suitability for species using correlations between present climate and known species occurrences. Moreover, modelling the occurrence of threatened and rare species at a reasonable scale is a very time-consuming and expensive process; it requires monitoring schemes to achieve the necessary sample size and can even be impossible when species are extremely rare or not the object of public interest (Engler et al., 2004; Wisz et al., 2008; Klausmeyer et al., 2011; Garcia et al., 2012; Summers et al., 2012). Finally, when the impact of climate change on species distribution and abundance is taken into account, a considerable source of uncertainty is added due to the difficulty of estimating how these two parameters will be affected by new climatic conditions (Thuiller et al., 2005; Kujala et al., 2013). Ecosystem modelling can overcome the shortcomings pinpointed by Watson et al. (2013) and fulfil the need of society to manage landscapes at a regional scale, simultaneously accounting for different species' responses to climate change, together with changes in landscape characteristics. An ecosystem approach would be more suitable than a species-specific approach to identify ecosystem adaptation strategies (Watson et al., 2013).

This article is protected by copyright. All rights reserved. 
Boreal forests are expected to be severely altered by climate change, as changes are likely to occur more quickly at higher latitudes (Eggers et al., 2008; Ruckstuhl et al., 2008; Lindner et al., 2010; Hickler et al., 2012). For decades, the dynamics and composition of boreal forests have been profoundly modified by human activity, i.e., by forestry, especially in Fennoscandia, and this is expected to continue in the future (Nabuurs et al., 2007). In northern Europe, increasing atmospheric $\mathrm{CO}_{2}$ and warmer temperatures are enhancing timber production as a consequence of speeding up forest growth, and the accumulation of carbon in the biomass is driven by the enhanced decomposition of soil organic matter and nitrogen supply (Eggers et al., 2008; Lindner et al., 2010; Hickler et al., 2012). In Finland, the distribution of tree species is also changing; broadleaved deciduous trees are expanding northwards, whereas Scots pine is increasing its dominance in the less fertile forest types in the south at the expense of Norway spruce (Kellomäki et al., 2008). A model-based approach has been developed for adapting current forest management practices to climate change to maximise profit from forests that are experiencing altered environmental conditions (Kellomäki et al., 2008). However, to maintain biodiversity, future forestry should also ensure the availability of coarse woody debris (CWD) at different stages of decay from different tree species (Tikkanen et al., 2006). CWD is an important resource and habitat for saproxylic, i.e., dead wood-dependent, species (Stokland et al., 2012). Dead wood can be considered an indicator of forest biodiversity (Lassauce et al., 2011). However, the response of red-listed saproxylic species to climate change is still poorly understood, even though identification of the best management regime for optimising both timber revenues and ecological diversity in forests is an important priority (Mönkkönen et al., 2014). The overall habitat availability (amount of dead wood) in boreal forests is expected to increase under scenarios of climate change. Nevertheless, dead wood availability will also depend on the management regime applied (Briceño-Elizondo et al., 2006; Garcia-Gonzalo et al., 2007;

This article is protected by copyright. All rights reserved. 
Mazziotta et al., 2014a). Intensive timber extraction, which is typical of Fennoscandian production forests, reduces dead wood availability through thinning and clear-cutting (Hynynen et al., 2005; Tikkanen et al., 2012). In contrast, forest protection increases habitat availability (the amount of dead wood) by favouring a higher diversity of dead wood stages (Hjältén et al., 2012; Gossner et al., 2013).

Our primary goal in this work was to conduct a climate change assessment of boreal forests, focusing on forests currently under intensive forest management regimes in northern Europe. Our study area spanned the entire latitudinal extent of the boreal forest from the hemiboreal to the northern boreal zone and encompassed a wide range of climatic conditions and human land use pressures. We defined the potential resilience of boreal landscapes by relating their current conservation capacity to their climate change vulnerability (Gillson et al., 2013). When applying this framework, we took into account the responses to climate change of a broad range of red-listed species with different habitat requirements. The use of this framework permitted us to assess the capacity of boreal forests for biodiversity conservation under climate change while avoiding the shortcomings identified by Watson $e t$ al. (2013).

We identified four categories of landscape based on responses to climate change in the landscape (Heller \& Zavaleta, 2009; Gillson et al., 2013): a) susceptible, i.e., the most intact forest regions highly vulnerable to climate change; b) resilient, i.e., relatively intact areas with low climatic vulnerability that could represent important climate refugia; c) resistant, i.e., forest regions with low current conservation capacity and low vulnerability to climate change; and d) sensitive, i.e., regions with low current conservation capacity and high This article is protected by copyright. All rights reserved. 
vulnerability to climate change. Conservation strategies for each landscape category were suggested based on current recommendations (Watson et al., 2013).

In our attempt to identify robust conservation strategies under future climatic uncertainty, we used three different IPCC emission scenarios to plan for a range of possible outcomes at landscape scales (Snover et al., 2013). Specifically, using data from plots of the Finnish National Forest Inventory, we investigated: (i) the conservation capacity of a boreal landscape for sustaining forest-dwelling species and the vulnerability of individual forest stands to climate change; (ii) the main patterns of the response values to climate change under alternative emission scenarios across the boreal vegetation zones; and (iii) which management strategies are needed to retain important habitats for dead wood-associated species under climate change.

\section{Materials and methods}

\section{Climatic data}

We used six climatic variables (temperature sum, number of dry days, evaporation, evapotranspiration, mean monthly temperature and precipitation) obtained from the Finnish Meteorological Institute and covering the entire area of Finland (Venäläinen et al., 2005; Jylhä, 2009), and the forest simulator projected these variables through the $21^{\text {st }}$ century (see Kellomäki et al., 2008 for further details). The baseline climate was calculated at a resolution of $10 \mathrm{~km}$ for the 1971-2000 period, whereas future climatic projections were calculated at a resolution of $49 \mathrm{~km}$ for the 2010-2099 period. Then, all variables were spatially joined to a resolution of $16 \mathrm{~km}$ in southern Finland and $32 \mathrm{~km}$ in northern Finland to match the National

This article is protected by copyright. All rights reserved. 
Forest Inventory (NFI) dataset. In both cases, the climatic data represented the daily values over seasons, thereby illustrating the inter-annual variability of the trends in the climatic variables. The interannual variability was simulated using the monthly mean temperature and precipitation with the standard deviations for the rotation time (tri-decadal averages and standard deviations). The annual mean values of atmospheric $\mathrm{CO}_{2}$ were used in the simulations. Under the baseline climate, atmospheric $\mathrm{CO}_{2}$ was constant at $352 \mathrm{ppm}$, whereas under the future expected climate, $\mathrm{CO}_{2}$ levels increased from the baseline value to different future levels. This was accompanied by changes in temperature and precipitation that were based on three emission scenarios of the Intergovernmental Panel on Climate Change (Nakicenovic et al., 2000): a high-emission scenario (A2), considered the most likely in the case of a world with regionally oriented economic development and featuring global average surface warming until 2100 of between +2.0 and $+5.4{ }^{\circ} \mathrm{C}$ and a continuous increase in emissions up to the end of the century; an intermediate-emission scenario (A1B) characterised by rapid economic growth in a more globalised world with balanced use of all energy sources and featuring global average surface warming of +1.7 to $+4.4{ }^{\circ} \mathrm{C}$ with an increase in the emissions up to 2050 at approximately the same rate as in the A2 scenario followed by a decrease to 2020 levels by the end of the century; and a low-emission scenario (B1), considered likely under the less plausible scenarios of globally oriented environmentally sustainable development and featuring global average surface warming of + 1.1 to $+2.9^{\circ} \mathrm{C}$, with an increase in emissions up to 2020 at a much lower rate than in the other scenarios followed by a stable emission period up to 2040 and a decrease close to zero emission levels by the end of the century (Raupach et al., 2007; Solomon, 2007; Jylhä, 2009).

This article is protected by copyright. All rights reserved. 
National Forest Inventory data

Our data consist of 2,816 permanent field plots from the $9^{\text {th }}$ Finnish National Forest Inventory (NFI) from the period 1996-2003 period (Finnish Forest Research Institute, 2010). The grid size of the plots is $16 \times 16 \mathrm{~km}^{2}$ in southern Finland and $32 \times 32 \mathrm{~km}^{2}$ in northern Finland. All plots have an extension of $100 \mathrm{~m}^{2}$ and are located on upland mineral soils. The site types of most of the plots can be classified as high, medium or low fertility, and include the following site types: a) herb-rich heath forests, with Norway spruce (Picea abies) as dominant species with admixtures of birch (Betula pendula and B. pubescens); b) mesic heath forests with a mixture of Norway spruce, birch and Scots pine (Pinus sylvestris); c) sub-xeric heath forests; and d) xeric heath forests in which the primary tree species is Scots pine (Cajander, 1949). Details concerning the relationships among site types and soil characteristics (classification, water holding capacity, fertility) and on the initialisation of the simulations are described in Kellomäki et al. (2008). To define an initial amount of litter accumulated in the soil prior to the simulation (background litter), simulations at tree level were first performed using pure stands (one tree species) (details in Appendix S1). The values obtained in these simulations were also used to calculate the initial amount of nitrogen in soil by applying the values of the total nitrogen concentration of the humus layer by site type and tree species (Kellomäki et al., 2008).

\section{Simulation procedures, model assumptions and performance}

The simulations were performed using SIMA, an individual tree-based ecosystem model that is a hybrid physiological and statistical model. In the model, regeneration is partly stochastic and partly controlled by the availability of light, soil moisture and temperature. Tree growth is based on the increase in tree diameter, which is the product of the potential diameter growth and four environmental factors: temperature sum, within-stand light conditions, soil

This article is protected by copyright. All rights reserved. 
moisture, and the availability of soil nitrogen. These factors control the demographic processes (recruitment, growth, death) of tree populations. Simulations are based on the Monte Carlo simulation technique, i.e., certain events such as tree recruitment and death are partly stochastic. Each time such an event is possible (e.g., when the conditions for a tree to die are verified), the algorithm determines whether the event will take place by comparing a random number with the probability of the occurrence of the event. The model structure and parameterisation are described in detail in Kellomäki (1992a, b), Kolström (1998) and Kellomäki et al. (2008). The model has been previously validated in Kolström (1998), Kellomäki et al. (2008), Routa et al. (2011), and Mazziotta et al. (2014a). A scheme of the interactions between factors and processes in the model is given in Fig. 1. Litter and dead trees are decomposed into soil with the subsequent release of nitrogen bound in soil organic matter. The litter cohort indicates the amount of dead material originating annually from trees and ground vegetation. The weight loss of a litter cohort is a function of the current ratio between lignin and nitrogen, and it depends on the available soil moisture and the degree of canopy closure. The mineralisation process of nitrogen depends on the nitrogen-carbon ratio of the humus and on the local climatic conditions (Pastor \& Post, 1986).

Forest dynamics were simulated by applying current Finnish management policy, which consists of two different management practices: (i) set-aside (SA), in which there is no management of the stands located within current public and private protected areas so as to guarantee natural forest succession (applied in 3\% of the total NFI plots); (ii) Business-AsUsual (BAU), which is the recommended management for providing revenues from timber extraction (Yrjölä, 2002) and is applied outside the protected areas (97\% of the NFI plots). BAU consists of a 60-80 year rotation, site preparation, planting or seeding trees, 1-3 thinnings per rotation, and a final harvest with a green tree retention level of 5 trees/ha.

This article is protected by copyright. All rights reserved. 
Details regarding the application of the rules for thinning and clear-cut practices are given in Kellomäki et al. (2008). In the model, the initial planting density was 2000 saplings/ha throughout the country, regardless of tree species and site type. To homogenise the treatment, the deterministic application of management rules was replaced by a random procedure that included no major changes in stocking at the beginning of the simulation (Kellomäki et al., 2008). The simulations were repeated 10 times to determine the central tendency of variations in behaviour of the forest ecosystem over time. The model was run on an annual basis for a typical rotation period of 90 years for each stand.

\section{Dead wood stock}

The dynamics of dead wood (expressed in $\mathrm{m}^{3} / \mathrm{ha}$ ) was simulated by SIMA for a succession period of 90 years for each of the four main boreal tree types/species (deciduous trees, consisting of pooled data for the deciduous trees Betula pendula, B. pubescens and Populus tremula; Scots pine, Pinus sylvestris; Norway spruce, Picea abies; and European aspen, Populus tremula) with documented importance for dead wood biodiversity (Stokland et al. 2012) and for the eight combinations of climatic scenarios (baseline climate, A2, A1B, and B1) and management regimes (SA and BAU). The dead wood pool was separated into two fractions at different stages of decomposition: fresh, i.e., stages 1 or 2 according to the classification of Stokland et al. (2001), and well-decayed, i.e., stages 3 or 4 according to that classification. Tikkanen et al. (2006) showed that the habitat association of saproxylic species with respect to decay stage can effectively be simplified into these two decomposition categories (definitions are given in Kouki \& Tikkanen, 2007).

This article is protected by copyright. All rights reserved. 
Selection of species habitat associations

Previous research (Tikkanen et al., 2006, 2007; Mönkkönen et al., 2011) has demonstrated that for the majority of red-listed saproxylic species in boreal forests habitat suitability can be determined according to few environmental variables at the stand level; these variables include microclimate conditions and the suitability of the existing resources. All possible combinations of stand level variables were used to define 35 habitat associations of the Finnish threatened saproxylic species included in the IUCN categories Near Threatened, Vulnerable, Endangered, and Critically Endangered) (Rassi et al., 2001) as reported in the Hertta database, the Environmental Information System of SYKE, the Finnish Environment Institute (Appendix S2). For each of these habitat associations, a Habitat Suitability Index (HSI) value was calculated as the product of two different sub-priority functions, translating stand characteristics into stand suitability for species (details of this process are given in Appendix S3). With respect to the microclimate, which is a function of the basal area of the living stock of stands, species can be classified as i) indifferent, i.e., insensitive to variation in the local microclimatic conditions, or as associated with ii) sun-exposed or iii) shady microhabitats. The suitability of the resources is a function of three components of dead wood: the tree species (pine, spruce, aspen, deciduous tree); the decay stage (fresh, well decayed); and the diameter association (no diameter association or association with large diameters $(>30 \mathrm{~cm})$ according to Tikkanen et al., 2006). In boreal forests, a large proportion of red-listed saproxylic species is represented by pine, spruce or birch/aspen trees (Tikkanen et al., 2006).

The shape and the parameters of the sub-priority functions (see Appendix S3) relating the probability of species presence to the states of different environmental variables can be estimated indirectly using information on the reported relationship between the amount of This article is protected by copyright. All rights reserved. 
dead wood or basal area of living stock and the richness of saproxylic species (Kouki \& Tikkanen, 2007; Mönkkönen et al., 2011). Particularly for dead wood availability, these relationships were deduced in previous studies for spruce (Martikainen et al., 2000; Penttilä et al., 2004; Stokland \& Larsson, 2011), pine (Similä et al., 2003; Junninen et al., 2006; Stokland \& Larsson, 2011), and deciduous trees (Martikainen, 2001; Hottola, 2003) or were estimated directly by the output of the simulator for aspen. In the latter case, we calculated for each $10-\mathrm{km}$ grid cell both the dead wood volume produced by the simulator and the number of records of species associated with a certain habitat type (e.g., fresh spruce dead wood) and estimated the curve parameter $b$ in Appendix S3. The equations relating species richness to microclimate and resources are modifications of the sub-priority functions proposed in Mönkkönen et al. (2011) and are reported in Appendix S3.

\section{Stand Conservation Capacity}

An estimate of the potential conservation capacity $(S C C)$ at the stand level (the landscape unit) was calculated for each NFI sample plot by weighing the habitat suitability across the $k$ = 35 habitat associations, as follows (cf. Pakkala et al., 2002):

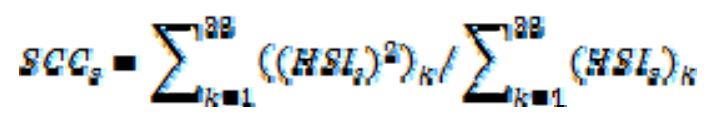

$H S I_{s}$ is the habitat suitability index $(H S I)$ calculated under a certain $s$ climatic

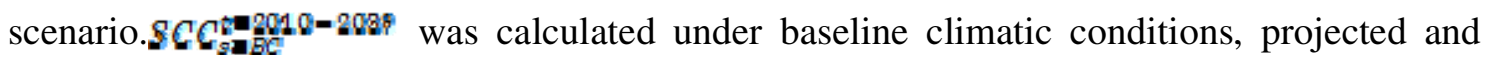
averaged across the first 3 simulated decades of the $21^{\text {st }}$ century $(t=2010-2039)$ for each

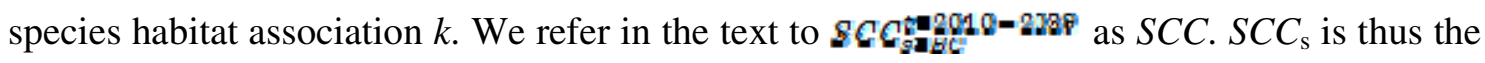
weighted average of HSI for specific habitat associations, the weights being the HSIs themselves. This places greater emphasis on large HSI-values and is ecologically more This article is protected by copyright. All rights reserved. 
meaningful than using the average values. SCCs range between 0 and 1, where 0 denotes a low conservation capacity and 1 high conservation capacity for all species habitat associations. We further categorised $S C C$ into five classes by means of the Jenks natural breaks classification method (Jenks, 1967), capturing the range of variability of SCC by reducing the variance within clusters of values and maximising the variance between classes. We then calculated the percentage of NFI plots included in each SCC category (Fig. 2a, Table $1)$.

\section{Climate Vulnerability}

Climate vulnerability $(C V)$ is a measure of the impact of climate change on $S C C$. $C V$ was calculated for each NFI sample plot by subtracting the SCC calculated under the three climate change scenarios $(s=B 1, A 1 B, A 2)$ from the $S C C s$ calculated under baseline climatic conditions $(s=B C)$, as follows:

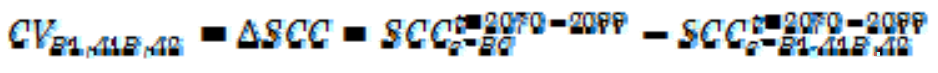

The habitat suitability indices used in the calculation of SCC under baseline and climate change conditions were averaged across the last three simulated decades of the $21^{\text {st }}$ century $(t$ $=2070-2099$ ), when the effects of climate change on forest dynamics are predicted to be the highest (Kellomäki et al., 2008). A negative $C V$ value corresponds to an increase in $S C C$ induced by climate change (improved landscape quality); a positive $C V$ value corresponds to a decrease in $S C C$ under climate change (landscape degradation). Because a given small change in habitat suitability induced by climate change is expected to have less biological importance when the initial level of SCC under baseline climate is either very low (close to 0 , e.g., an increase from 0.01 to 0.06 ) or very high (close to 1, e.g., an increase from 0.94 to

This article is protected by copyright. All rights reserved. 
0.99 ) and greater importance when $S C C$ values are intermediate (e.g., between 0.47 and 0.52 , i.e., transcending the 0.5 threshold), we transformed the $C V$ values as follows and, finally, rescaled them to between 0 and 1 :

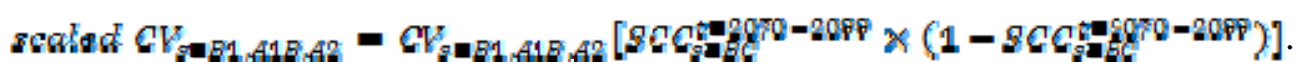

We mapped the scaled $C V_{s}$ for NFI stands in Finland for each climate change scenario and divided the values into five categories: (i) $-1.00 \leq C V \leq 0.00$; (ii) $0.00<C V \leq 0.25$; (iii) $0.25<C V \leq 0.50$; (iv) $0.50<C V \leq 0.75$; and (v) $0.75<C V \leq 1.00$ (Fig. 2b,c,d and Table 1). The thresholds for separating $C V$ categories were chosen using the Jenks natural breaks classification method, and the percentages of NFI plots included in each $C V$ category were calculated.

Recent research has shown that biogeographical boundaries may be more effective than administrative boundaries for planning forest conservation actions (Gustafsson et al., 2014). To summarise the variability in the $S C C$ and $C V$ values for each of the four vegetation zones (hemiboreal, southern, central and northern boreal) described by Hämet-Ahti (1981), we calculated the mean values for each zone. The dependence between the response variables ( $S C C$ and $C V$ ) and the vegetation zones as categorical predictor variables was analysed using generalised estimating equations (GEEs) (Hardin and Hilbe 2003). The GEE accounts for the spatial correlation in the values of the response variables (Albert \& McShane, 1995). The GEE focuses on estimating the average response over all the stands "population", whereas the use of regression parameters permits prediction of the effects of changing one or more covariates on a given individual stand. The GEE method is based on quasilikelihood theory; i.e., it is not necessary that the distribution of the dependent variables be normal. For both of 
the response variables, we assumed a gamma distribution of errors (random part of the model) and a log link function (systematic part) between the dependent variable and the categorical predictor. The means of the GEE regression parameters for $S C C$ and $C V$ were calculated by means of the Wald test using robust standard errors.

\section{Response categories under climate change}

Categorisation of the Finnish NFI sample plots based on their response to climate change was conducted by allocating them in a biplot (Fig. 3) on the basis of their values for the SCC and the $C V$, which are independent axes, being calculated for different time periods, $S C C$ for the first 30 years and $C V$ for the last 30 years of the 21 st century, in accordance with the classification proposed by Gillson et al. (2013), as follows: a) susceptible plots, with SCC > 0.5 and $C V>0$; b) resilient plots, with $S C C>0.5$ and $C V<0$; c) resistant plots, with $S C C<$ 0.5 and $C V<0$; and d) sensitive plots, with $S C C<0.5$ and $C V>0$. The response value for each plot was obtained by multiplying the absolute value of the $S C C$ under baseline climate conditions by the $C V$ of each climate change emission scenario. Stands with higher response values were those at greater absolute distances from the axis origin (Fig. 3). For each category, we compared the occurrence and response values of the NFI plots across (i) the emission scenarios and (ii) the boreal forest zones. The mean response values were compared using the GEE method (see previous paragraph). Comparison among vegetation zones allows definition of how alternative conservation strategies should be assigned among the regions. For each emission scenario, the response values of each category were mapped (Fig. 4). The response values were separated into five classes (very low, low, intermediate, high, and very high), the thresholds of which were based on natural breaks (Jenks). For each category, the threshold response values were the same across the three emission scenarios.

This article is protected by copyright. All rights reserved. 
The present attempt at landscape planning under climate change has potential limitations due to various factors, which are summarised in Appendix S4. All spatial analyses were performed using the Geographic Information System software ArcGIS 10 Desktop (ESRI, 2011). All statistical analyses were performed using SPSS 20.0 (IBM Corp., 2011).

\section{Results}

\section{Stand Conservation Capacity}

The potential SCC of the Finnish NFI plots for forest-dwelling species associated with dead wood was rather low. In fact, only $26.9 \%$ of the NFI sample plots showed values higher than 0.5 , and $73.1 \%$ had values lower than or equal to 0.5 , and optimal NFI plots (with $S C C>$ 0.75 ) represented only $2.5 \%$ of the total (Table 1 ). However, plots with habitat quality between 0.25 and 0.50 represented almost half of all the NFI data, and stands with low to very low habitat quality $(S C C \leq 0.25)$ made up a significant fraction of the total NFI $(28.3 \%)$ (Table 1). The mean $S C C$ values differed among boreal forest zones (Wald Chi-square = 86.0, d.f. $=3, P<0.001$ ); mean SCC values were equal in the hemiboreal and southern boreal zones but decreased towards the central and the northern boreal zones (Fig. 2a).

\section{Climate Vulnerability}

At the end of the $21^{\text {st }}$ century under all the emission scenarios considered, the conservation capacity decreased $(C V>0)$ in more than $90 \%$ of the NFI plots studied (Table 1). The decrease in landscape quality was lower under the low-emission scenario (B1), for which the majority of the plots had $C V s$ between 0 and 0.25 , than under the intermediate- (A1B) and high- (A2) emission scenarios, for which the majority of the plots had $C V s$ between 0.25 and

This article is protected by copyright. All rights reserved. 
0.50. The intermediate-emission scenario (A1B), with a quarter of the plots showing $C V \mathrm{~s}$ between 0.50 and 0.75 , decreased landscape quality even more than the high-emission scenario, which had more stands in the $C V$ interval between 0.10 and 0.25 (Fig. 2b,c,d; Table 1). However, towards the end of the $21^{\text {st }}$ century, an increase in conservation capacity $(C V<$ 0 ) occurred for a very low fraction of the NFI plots (always $<10 \%$ ) irrespective of the emission scenario, although this fraction was slightly higher under the low-emission scenario (B1) (Table 1). The mean values of climatic vulnerability differed among boreal forest zones (Wald Chi-square (d.f. $=2$, all $P \leq 0.05):(B 1)=21.8,($ A1B $)=23.7,($ A2) $=7.7)($ Fig. 2b,c,d). For all of the emission scenarios, mean climate vulnerability was significantly higher in the southern boreal zone than in the central boreal zone. Moreover, under the intermediate(A1B) and high- (A2) emission scenarios, climate vulnerability in the southern boreal zone was also significantly higher than in the northern boreal zone.

\section{Climate change response categories}

The proportion and response values of the four categories varied among the emission scenarios and for some categories among the vegetation zones, as follows (Figs. 3-4; Table 2):

a) Susceptible $(\mathrm{B} 1=24.7 \%, \mathrm{~A} 1 \mathrm{~B}=26.4 \%, \mathrm{~A} 2=26.2 \%)$ : the most intact forest plots vulnerable to climate change represented one quarter of the Finnish forest landscape irrespective of the emission scenario. The mean response values of susceptible plots were highest in the intermediate-emission scenario (A1B), intermediate in the high-emission scenario and lowest in the low-emission scenario (Wald $=936.9$, d.f. $=2, P<0.001)$. The mean response values of susceptible plots did not significantly differ among the vegetation zones under the low-emission scenario (B1, Wald $=7.3$, d.f. $=3, P=0.062$ ). However, under This article is protected by copyright. All rights reserved. 
the intermediate- $(\mathrm{A} 1 \mathrm{~B}$, Wald $=24.0$, d.f. $=3, P<0.001)$ and high- $(\mathrm{A} 2$, Wald $=12.3$, d.f. $=$ 3, $P=0.006)$ emission scenarios, the mean response value of susceptible plots was significantly higher in the northern boreal vegetation zone than in the other zones. Moreover, under the intermediate- (A1B) emission scenario, the response value of susceptible stands was significantly higher in the hemi- and southern boreal zones than in the central boreal zone.

b) Resilient ( $\mathrm{B} 1=2.2 \%, \mathrm{~A} 1 \mathrm{~B}=0.5 \%, \mathrm{~A} 2=0.6 \%)$ : intact plots with low climatic vulnerability were infrequent in the Finnish forest landscape. The mean response values of resilient plots did not differ among the emission scenarios (Wald $=3.9$, d.f. $=2, P=0.144$ ) or among the vegetation zones under the low- $(\mathrm{B} 1$, Wald $=3.0$, d.f. $=3, P=0.384)$ and high(A2, Wald $=8.1$, d.f. $=3, P=0.06)$ emission scenarios. By contrast, under the intermediateemission (A1B) scenario, there were differences in the mean response values of resilient plots among the zones (Wald $=19.0$, d.f. $=3, P<0.001$ ), with the values being lower in the northern boreal vegetation zone than in the other zones.

c) Resistant $(\mathrm{B} 1=6.7 \%, \mathrm{~A} 1 \mathrm{~B}=0.8 \%, \mathrm{~A} 2=1.1 \%)$ : plots with low current conservation capacity and low vulnerability to climate change were infrequent in the Finnish forest. The mean response value of resistant plots was not significantly different among the emission scenarios (Wald $=0.8$, d.f. $=2, P=0.659$ ). There were statistically significant differences between regions in the mean response value of resistant plots in all climate change scenarios (B1, Wald $=8.0$, d.f. $=3, P=0.046 ;$ A1B, Wald $=18.8$, d.f. $=3, P<0.001$; A2, Wald $=72.7$, d.f. $=3, P<0.001$ ) ; however, judging from the absolute mean values (Table 2), these differences may not be considerable in most cases.

This article is protected by copyright. All rights reserved. 
d) Sensitive (B1=66.4\%, A1B=72.3\%, A2=72.0\%): low conservation capacity plots vulnerable to climate change represented the majority (at least two thirds) of the stands under all the emission scenarios. The mean response values of sensitive plots differed among the emission scenarios (Wald $=815.3$, d.f. $=2, P<0.001$ ); they were highest in the intermediateemission scenario (A1B) and lowest in the low-emission scenario. In all emission scenarios, the mean response values of sensitive plots differed among boreal forest zones $((\mathrm{B} 1)=32.5$; $(\mathrm{A} 1 \mathrm{~B})=94.8 ;(\mathrm{A} 2)=60.2$; in all cases d.f. $=3, P<0.001)$ and were lower in the northern boreal zone than in the other three zones.

\section{Discussion}

Our modelling approach provides an assessment of the conservation status of the boreal forest in Finland under climate change that avoids the shortcomings discussed by Watson et al. (2013). We identify categories of response under various scenarios of climate change in a spatially explicit way, taking into account two of the three components of climate vulnerability (exposure and sensitivity). In our assessment, these challenges are addressed as follows: (1) accounting for the response at the ecosystem level is possible because the simulator provides information about potential suitable habitats for forest species given certain conditions of the forest stands and stand conditions are derived directly from the population parameters during the forest succession, which are influenced by the applied climatic scenario and the forest management; (2) mapping the pattern and value of each response category is conducted for phytogeographic zones, and both conservation capacity and vulnerability are based on metrics calculated at the level of the landscape unit (the stand); (3) calculating climate vulnerability accounts both for the exposure of stands (because the effects of climate change on stand conservation capacity varies with geographic location) and

This article is protected by copyright. All rights reserved. 
for their sensitivity (because species sharing different habitat associations respond differently to climate change effects).

\section{Conservation capacity and climate vulnerability}

Overall, the current conservation capacity of boreal forests in Finland was shown to be rather low. This is due to intensive management for timber extraction, which has been shown to have strong negative effects on biodiversity (Mönkkönen, 1999) and in particular on the resource availability of species associated with dead wood (cf. Chapin III et al., 2007; Ranius \& Roberge, 2011; Stockland et al., 2012; Mazziotta et al., 2014a). Conservation capacity will likely remain low if additional actions such as restoration measures are not taken to increase it in the future. The low current conservation capacity of Finland's forests was particularly prominent for forests in the northern boreal zone. Indeed, forests in the southern vegetation zones are currently characterised by a larger proportion of deciduous trees, harbouring higher habitat diversity, and hence by greater potential to host species than forests in the north (Tikkanen et al., 2009). The low current conservation capacity of these forests and the very strong decrease in conservation capacity expected by the end of the $21^{\text {st }}$ century are of concern because they confirm earlier research findings that climate change effects on biodiversity will likely be stronger in landscapes subject to intensive human land use (Travis, 2003; Bomhard et al., 2005; Brook et al., 2008; Barbet-Massin et al., 2012). Biodiversityfriendly management strategies such as set-aside are likely to serve as better buffers than production forests for climate change effects (cf. Chapin III et al., 2007; Driscoll et al., 2012).

Climate change is expected to have a stronger effect at higher latitudes and to produce more dead wood in the northern boreal zone. However, because of the productivity gradient

This article is protected by copyright. All rights reserved. 
from higher to lower latitudes, we would expect higher dead wood volumes in centralsouthern boreal forests than further north and, as a corollary, higher stand conservation capacity for forest-dwelling species (Kellomäki et al., 2008; Mazziotta et al., 2014a). An increased decomposition rate (Shorohova et al., 2008; Tuomi et al., 2011) and more frequent harrowing (i.e., site preparation practices) (Rabinowitsch-Jokinen \& Vanha-Majamaa, 2010; Hautala et al., 2011) are likely to contribute to more rapid dead wood removal. The faster dead wood dynamics will likely provide less time for forest species to use the higher volumes of resources produced under climate change (cf. Eggers et al., 2008; Mazziotta et al., 2014a).

The current very low level of forest protection and the high degree of fragmentation of old forests that are largely confined to woodland key habitats in southern Finland (Laita et al., 2010; Timonen et al., 2010) require additional conservation actions (Lehtomäki et al., 2009). We emphasise the need for larger protected areas and careful planning to improve the landscape quality to favour the dispersal of forest-dwelling species whose habitat, particularly in the southern boreal zone, is expected to become even more degraded by climate change.

\section{Climate change response categories and adaptation strategies}

Through the categorisation of the landscape, our framework permits the identification of areas that should be selected for the application of different adaptation strategies. In synthesis, our results indicate that, irrespective of the emission scenario, the Finnish landscape will likely be dominated by a very high proportion of sensitive and susceptible forest patches, whereas resilient and resistant patches are likely to be relatively rare in the landscape. This means that most forests, irrespective of their conservation capacity, will be vulnerable to climate change, strongly reducing the potential for species persistence and 
adaptation to new climates. This increased fragility of the landscape translates into a higher uncertainty for landscape managers in the choice of conservation strategies. However, the response values of susceptible and sensitive plots will likely be lowest under the lowemission scenario (B1), intermediate under the high-emission scenario (A2) and highest under the intermediate-emission scenario (A1B). The fact that the highest proportion of susceptible and sensitive categories is found under the A1B scenario could be explained by the fact that this scenario includes the highest biofuel harvest of all the scenarios (Eggers et al., 2008), a factor that is likely to jeopardise forest biodiversity in different ways (Riffell et al., 2011; Bouget et al., 2012). However, the response values of resilient and resistant plots are similar under different emission scenarios. Although the value of the climate change response categories differs across the vegetation zones under different emission scenarios and no unequivocal pattern can be observed, the information provided herein can be useful to inform conservation efforts in different vegetation zones.

With respect to biodiversity conservation, an ideal situation would be to have a high proportion of resilient forests. Our results show that the frequency of such forests in current landscapes is very low irrespective of the emission scenario; thus, alternative conservation actions are needed to improve the situation. In the few resilient forest patches, which can act as important climate refugia, conservation actions ranging from selective logging to full protection (set-aside) (Chapin III et al., 2007) for maintaining and monitoring high landscape conservation capacity should be delivered (Heller \& Zavaleta, 2009; Gilsson et al., 2013; Watson et al., 2013) across all the vegetation zones under both the low- (B1) and high- (A2) emission scenarios and should be pursued more aggressively in the southernmost boreal zones under intermediate (A1B) emissions. In susceptible patches, conservation actions for maintaining high conservation capacity and enhancing heterogeneity (and thereby resilience)

This article is protected by copyright. All rights reserved. 
by permanently or temporarily protecting biodiverse forest reserves are recommended (Mönkkönen et al., 2011). While under low (B1) emissions, protection is less needed in all the vegetation zones; under intermediate- (A1B) and high- (A2) emission scenarios, protection would be more required in the northern boreal zone. The several resistant patches are recommended for restoration projects, which should improve their habitat quality and enhance their connectivity, transforming them into resilient patches (Halme et al., 2013). These measures would increase the reservoir areas for forest species where the velocity of climate change is less critical and adaptation is still possible in all the vegetation zones.

Sensitive stands require alternative measures, but achieving resiliency may be difficult as both conservation capacity and climate vulnerability will need to be managed. This is easiest for sensitive areas that show a relatively low vulnerability ( $C V$ only slightly positive) and relatively high conservation capacity ( $S C C$ close to 0.5 ). Forests requiring restoration to improve SCC and management for heterogeneity to reduce vulnerability would be more common under a low- (B1) emission scenario, especially in the northern boreal zone. At the opposite end of the continuum are the highly sensitive areas, which are very vulnerable and possess low conservation capacity. These are particularly common under the intermediate(A1B) emission scenario and in the southernmost boreal zones. For such forests, neglect is often suggested so as to permit the effective allocation of scarce conservation resources elsewhere (Heller \& Zavaleta, 2009; Gilsson et al., 2013; Watson et al., 2013; Alagador et al., 2014). Mazziotta et al. (2014b) showed that setting aside clear-cuts in certain boreal forest types would be a cost-efficient conservation action in the long run. Setting aside clear-cuts could complement more traditional conservation of old forests: indeed, acquiring such stands for conservation purposes is relatively inexpensive, and their conservation capacity will improve over time. Therefore, we recommend considering setting aside clear-cuts in boreal

This article is protected by copyright. All rights reserved. 
settings as a management action for highly sensitive forests such as those in the southernmost boreal zones.

Our study, which was conducted using an ecosystem model, represents a novel application of the conservation capacity versus climate change vulnerability framework. There are some factors that limit our approach: i) the forest simulator did not include potential tree species migration in the forest plot driven by climate change; and ii) there are uncertainties related to future climate change scenarios (see additional details in Appendix S4). Nevertheless, the application of the framework to Finland's forests at a national scale has proven to be important for finding combinations of emission scenarios and vegetation zones in which particular landscape climate change response categories occur frequently and at high response values. These indications can be used to design management/adaptation interventions for those regions at a local scale. Systematic planning of the landscape to accommodate adaptation strategies for climate change is an essential tool in efficiently allocating the usually limited budget available for conservation-oriented measures (cf. Lindenmayer et al., 2007; Alagador et al., 2014; Mazziotta et al., 2014b). In this study, we demonstrate that use of an ecosystem simulator together with inventory data and general knowledge of species ecology can facilitate achieving this goal. In any case, increased investment in conservation actions pursued at the ecosystem level could be required to improve landscape conservation capacity, thus buffering the increasingly negative effect of climate change on the persistence of forest species (Mori et al., 2013; Watson et al., 2013).

\section{Acknowledgments}

A.M., M.T. and M.M. thank the Academy of Finland (project 138032) for financial support. This work was also supported by the ongoing consortium project ADAPT (proj. 14907, 2012-

This article is protected by copyright. All rights reserved. 
2016), funded by the Academy of Finland, University of Eastern Finland (consortium project and team 1 led by Prof. Heli Peltola) and Finnish Meteorological Institute (team 2 led by Dr Jussi Kaurola). We thank Finnish Meteorological Institute for providing the grid based ACCLIM climate scenarios throughout Finland and Metla, the Finnish Forest Research Institute, for the perusal of the sub-sample of data on from the 9th National Forest Inventory. Furthermore, we gratefully acknowledge Prof. S. Kellomäki (School of Forest Sciences, University of Eastern Finland) for further development of SIMA model and instructions given for its use, which were needed for implementation of this research work. We thank SYKE, the Finnish Environment Institute, for the perusal of the data from the Hertta database. Finally we are grateful to P. Halme, D. Podkopaev, T. Pohjanmies, K. Raatikainen and S. Varga for improving the manuscript with their comments and discussions.

\section{References}

Alagador D, Gerdeira JO, Araújo MB (2014) Shifting protected areas: scheduling spatial priorities under climate change. Journal of Applied Ecology, doi: 10.1111/1365-2664.12230.

Albert PS, McShane LM (1995) A Generalized Estimating Equations approach for spatially correlated binary data: applications to the analysis of neuroimaging data. Biometrics, 51, 627638.

Barbet-Massin M, Thuiller W, Jiguet F (2012) The fate of European breeding birds under climate, land-use and dispersal scenarios. Global Change Biology, 18, 881-890.

Bellard C, Bertelsmeier C, Leadley P, Thuiller W, Courchamp F (2012) Impacts of climate change on the future of biodiversity. Ecology Letters, 15, 365-377.

This article is protected by copyright. All rights reserved. 
Bomhard B, Richardson DM, Donaldson JS et al. (2005) Potential impacts of future land use and climate change on the Red List status of the Proteaceae in the Cape Floristic Region, South Africa. Global Change Biology, 11, 1452-1468.

Bouget C, Lassauce A, Jonsell M (2012) Effects of fuelwood harvesting on biodiversity - a review focused on the situation in Europe. Canadian Journal of Forest Research, 42, 14211432.

Brook BW, Sodhi NS, Bradshaw CJA (2008) Synergies among extinction drivers under global change. Trends in Ecology \& Evolution, 23, 453-460.

Briceño-Elizondo E, Garcia-Gonzalo J, Peltola H, Matala H, Kellomäki S (2006) Sensitivity of growth of Scots pine, Norway spruce and silver birch to climate change and forest management in boreal condition. Forest Ecology and Management, 232, 152-167.

Cajander AK (1949) Forest Types and Their Significance. Acta Forestalia Fennica 56, 1-71.

Chapin III FS, Danell K, Elmqvist T, Folke C, Fresco N (2007) Managing climate change impacts to enhance the resilience and sustainability of Fennoscandian forests. Ambio, 36, 528-533.

Convention on Biological Diversity (2010) COP 10 Decision X/2: Strategic Plan for Biodiversity 2011-2020. <http://www.cbd.int/decision/cop/?id=12268>

Cramer W, Bondeau A, Woodward F et al. (2001) Global response of terrestrial ecosystem structure and function to $\mathrm{CO} 2$ and climate change: results from six dynamic global vegetation models. Global Change Biology, 7, 357-373.

This article is protected by copyright. All rights reserved. 
Crossman ND, Bryan BA, Summers DM (2012) Identifying priority areas for reducing species vulnerability to climate change. Diversity and Distributions, 18, 60-72.

Dawson TP, Jackson ST, House JI, Prentice IC, Mace GM (2011) Beyond predictions: biodiversity conservation in a changing climate. Science, 332, 53-58.

Driscoll DA, Felton A, Gibbons P, Felton AM, Munro NT, Lindenmayer DB (2012) Priorities in policy and management when existing biodiversity stressors interact with climate-change. Climatic Change, 111, 533-557.

Eggers J, Lindner M, Zudin S, Zaehle S, Liski J (2008) Impact of changing wood demand, climate and land use on European forest resources and carbon stocks during the 21 st century. Global Change Biology, 14, 2288-2303.

Engler R, Guisan A, Rechsteiner L (2004) An improved approach for predicting the distribution of rare and endangered species from occurrence and pseudo-absence data. Journal of Applied Ecology, 41, 263-274.

ESRI (2011) ArcGIS Desktop: Release 10. Redlands, CA: Environmental Systems Research Institute.

Finnish Forest Research Institute (2010) Finnish Statistical Yearbook of Forestry. Metla, Vantaa. http://www.metla.fi/index-en.html

Garcia RA, Burgess N, Cabeza M, Rahbek C, Araújo M (2012) Exploring consensus in $21^{\text {st }}$ century projections of climatically suitable areas for African vertebrates. Global Change Biology, 18, 1253-1269.

This article is protected by copyright. All rights reserved. 
Garcia-Gonzalo J, Peltola H, Briceño-Elizondo E, Kellomäki S (2007) Changed thinning regimes may increase carbon stock under climate change: a case study from a Finnish boreal forest. Climatic Change, 81,431-454.

Gillson L, Dawson TP, Jack S, McGeoch MA (2013) Accommodating climate change contingencies in conservation strategy. Trends in Ecology \& Evolution, 28, 135-142.

Gossner MM, Lachat T, Brunet J et al. (2013) Current near-to-nature forest management effects on functional trait composition of saproxylic beetles in beech forests. Conservation Biology, 27, 605-614.

Gustafsson L, Felton A, Felton AM et al. (2014) Natural versus national boundaries: the importance of considering biogeographical patterns in forest conservation policy.

Conservation Letters. doi: 10.1111/conl.12087

Halme P, Allen KA, Auninš A et al., (2013) Challenges of ecological restoration: Lessons from forests in northern Europe. Biological Conservation, 167,248-256

Hanski I, Ovaskainen O (2000) The metapopulation capacity of a fragmented landscape. Nature, 404, 755-758.

Hautala H, Laaka-Lindberg S, Vanha-Majamaa I (2011) Effects of retention felling on epixylic species in boreal spruce forests in southern Finland. Restoration Ecology, 19, 418429.

Heller NE, Zavaleta ES (2009) Biodiversity management in the face of climate change: A review of 22 years of recommendations. Biological Conservation, 142, 14-32.

This article is protected by copyright. All rights reserved. 
Hickler T, Vohland K, Feehan J et al. (2012) Projecting the future distribution of European potential natural vegetation zones with a generalized, tree species-based dynamic vegetation model. Global Ecology and Biogeography, 21, 50-63.

Hjältén J, Stenbacka F, Pettersson RB et al. (2012) Micro and macro-habitat associations in saproxylic beetles: implications for biodiversity management. PLoS ONE, 7, e41100.

Hottola J (2003) Kääpäyhteisön rakenne suhteessa lahopuustonvrakenteeseen Vaara-Karjalan ja Kuhmon sekä Venä jän Karjalan metsissä . M.Sc. Thesis, Department of Biology, University of Oulu, 113 p. (in Finnish)

Hämet-Ahti L (1981) The boreal zone and its biotic subdivisions. Fennia, 159, 69-75.

Hynynen J, Ahtikoski A, Siitonen J, Sievänen R, Liski J (2005) Applying the MOTTI simulator to analyse the effects of alternative management schedules on timber and nontimber production. Forest Ecology and Management, 207, 5-18.

Jenks GF (1967) The Data Model Concept in Statistical Mapping, International Yearbook of Cartography, 7, 186-190.

Junninen K, Similä M, Kouki J, Kotiranta H (2006) Assemblages of wood-inhabiting fungi along the gradients of succession and naturalness in boreal pine-dominated forests in Fennoscandia. Ecography, 29, 75-83.

Jylhä K (2009) Arvioita Suomen muuttuvasta ilmastosta sopeutumistutkimuksia varten. ACCLIM-hankkeen raportti 2009. - Rapoetteja _ Rapporter_ Reports. (The changing climate in Finland: estimates for adaptation studies. ACCLIM project report 2009.) Ilmatieteen laitos, Raportteja 2009: 4, 102 s. In Finnish, abstract, extended abstract and captions for figures and tables in English)

This article is protected by copyright. All rights reserved. 
Kellomäki S. (1992a) SIMA: A model for forest succession based on the carbon and nitrogen cycles with application to silvicultural management of the forest ecosystem. Joensuun yliopisto, [Joensuu].

Kellomäki S (1992b) A simulation model for the succession of the boreal forest ecosystem. Silva Fennica, 26, 1-18.

Kellomäki S, Peltola H, Nuutinen T, Korhonen KT, Strandman H (2008) Sensitivity of managed boreal forests in Finland to climate change, with implications for adaptive management. Philosophical Transactions of the Royal Society B: Biological Sciences, 363, 2339-2349.

Klausmeyer KR, Shaw MR, MacKenzie JB, Cameron DR (2011) Landscape-scale indicators of biodiversity's vulnerability to climate change. Ecosphere, 2, 1-18.

Kolström M (1998) Ecological simulation model for studying diversity of stand structure in boreal forests. Ecological Modelling, 111, 17-36.

Kouki J, Tikkanen O-P (2007) Uhanalaisten lahopuulajien elinympäristöjen turvaaminen suojelualueilla ja talousmetsissä : kustannustehokkuus ja ekologiset, ekonomiset sekä sosiaaliset vaikutukset Kitsin seudulla Lieksassa. Ympäristöministeriö, Helsinki, 104 s pp.

Kujala H, Moilanen A, Araújo MB, Cabeza M (2013) Conservation Planning with Uncertain Climate Change Projections. PLoS ONE, 8(2), e53315. doi:10.1371/journal.pone.0053315

IBM Corp (2011) IBM SPSS Statistics for Windows, Version 20.0. IBM Corp, Armonk, NY

Laita A, Mönkkönen M, Kotiaho J S (2010) Woodland key habitats evaluated as part of a functional reserve network. Biological Conservation, 143, 1212-1227.

This article is protected by copyright. All rights reserved. 
Lassauce A, Paillet Y, Jactel H, Bouget C (2011) Deadwood as a surrogate for forest biodiversity: Meta-analysis of correlations between deadwood volume and species richness of saproxylic organisms. Ecological Indicators, 11, 1027-1039.

Lehtomäki J, Tomppo E, Kuokkanen P, Hanski I, Moilanen A (2009) Applying spatial conservation prioritization software and high-resolution GIS data to a national-scale study in forest conservation. Forest Ecology and Management, 258, 2439-2449.

Lindenmayer DB, Fischer J, Felton A et al. (2007) The complementarity of single-species and ecosystem-oriented research in conservation research. Oikos, 116, 1220-1226.

Lindner M, Maroschek M, Netherer S et al. (2010) Climate change impacts, adaptive capacity, and vulnerability of European forest ecosystems. Forest Ecology and Management, 259, 698-709.

Mantyka-Pringle CS, Martin TG, Rhodes JR (2012) Interactions between climate and habitat loss effects on biodiversity: a systematic review and meta-analysis. Global Change Biology, $18,1239-1252$.

Martikainen P (2001) Conservation of threatened saproxylic beetles: significance of retained aspen Populus tremula on clearcut areas. Ecological Bulletins, 49, 205-218.

Martikainen P, Siitonen J, Punttila P, Kaila L, Rauh J (2000) Species richness of Coleoptera in mature managed and old-growth boreal forests in southern Finland. Biological Conservation, 94, 199-209.

Mazziotta A, Mönkkönen M, Strandman H, Routa J, Tikkanen O-P, Kellomäki S (2014a) Modeling the effects of climate change and management on the dead wood dynamics in

This article is protected by copyright. All rights reserved. 
boreal forest plantations. European Journal of Forest Research, 133, 405-421. DOI

10.1007/s10342-013-0773-3.

Mazziotta A, Pouzols FM, Mönkkönen M, Kotiaho JS, Strandman H, Moilanen A (2014b)

Optimal conservation resource allocation under variable economic and ecological discounting rates: when does it pay to set aside degraded habitats in boreal forest? Biological

Conservation

Mönkkönen M (1999) Managing Nordic boreal forest landscapes for biodiversity: ecological and economic perspectives. Biodiversity and Conservation, 8, 85-99.

Mönkkönen M, Juutinen A, Mazziotta A, Miettinen K, Podkopaev D, Reunanen P, Salminen H, Tikkanen O-P (2014) Spatially dynamic forest management to sustain biodiversity and economic returns. Journal of Environmental Management, 134, 80-89.

Mönkkönen M, Reunanen P, Kotiaho JS, Juutinen A, Tikkanen O-P, Kouki J (2011) Costeffective strategies to conserve boreal forest biodiversity and long-term landscape-level maintenance of habitats. European Journal of Forest Research, 130, 717-727.

Mori AS, Spies TA, Sudmeier-Rieux K, Andrade A (2013) Reframing ecosystem management in the era of climate change: Issues and knowledge from forests. Biological Conservation, 165, 115-127.

Nakicenovic N, Alcamo J, Davis G et al. (2000) Special Report on Emissions Scenarios: A Special Report of Working Group III of the Intergovernmental Panel on Climate Change. Cambridge University Press, Cambridge, UK.

Nabuurs GJ, Pussinen A, van Brusselen J, Schelhaas MJ (2007) Future harvesting pressure on European forests. European Journal of Forest Research, 126, 391-400.

This article is protected by copyright. All rights reserved. 
Oliver TH, Smithers RJ, Bailey S, Walmsley CA, Watts K (2012) A decision framework for considering climate change adaptation in biodiversity conservation planning. Journal of Applied Ecology, 49, 1247-1255.

Pakkala T, Hanski I, Tomppo E (2002) Spatial ecology of the three-toed woodpecker in managed forest landscapes. Silva Fennica, 36, 279-288.

Parmesan C (2006) Ecological and evolutionary responses to recent climate change. Annual Review of Ecology Evolution and Systematics, 37, 637-669.

Pastor J, Post WM (1986) Influence of climate, soil moisture, and succession on forest carbon and nitrogen cycles. Biogeochemistry, 2, 3-27.

Penttilä R, Siitonen J, Kuusinen M (2004) Polypore diversity in managed and old-growth boreal Picea abies forests in southern Finland. Biological Conservation, 117, 271-283.

Ranius T, Roberge J (2011) Effects of intensified forestry on the landscape-scale extinction risk of dead wood dependent species. Biodiversity and Conservation, 20, 2867-2882.

Raupach MR, Marland G, Ciais P, Le Quéré C, Canadell JG, Klepper G, Field CB (2007) Global and regional drivers of accelerating CO2 emissions. Proceedings of the National Academy of Sciences, 104, 10288-10293.

Rassi P, Alanen A, Kanerva T, Mannerkoski I (2001) The 2000 Red List of Finnish Species (Ministry of the Environment and Finnish Environment Institute, Helsinki).

Riffell S, Verschuyl J, Miller D, Wigley B (2011) Biofuel harvests, coarse woody debris, and biodiversity - A meta-analysis. Forest Ecology and Management, 261, 878-887.

This article is protected by copyright. All rights reserved. 
Routa J, Kellomäki S, Peltola H, Asikainen A (2011) Impacts of thinning and fertilization on timber and energy wood production in Norway spruce and Scots pine: scenario analyses based on ecosystem model simulations. Forestry, 84, 159-175.

Ruckstuhl KE, Johnson EA, Miyanishi K (2008). Introduction. The boreal forest and global change. Philosophical Transactions of the Royal Society B: Biological Sciences, 363, 22432247.

Rabinowitsch-Jokinen R, Vanha-Majamaa I (2010) Immediate effects of logging, mounding and removal of logging residues and stumps on coarse woody debris in managed boreal Norway spruce stands. Silva Fennica, 44, 51-62.

Schmitz O, Post E, Burns C, Johnston K (2003) Ecosystem responses to global climate change: Moving beyond color mapping. Bioscience, 53, 1199-1205.

Shorohova E, Kapitsa E, Vanha-Majamaa I (2008) Decomposition of stumps in a chronosequence after clear-felling versus clearfelling with prescribed burning in a southern boreal forest in Finland. Forest Ecology and Management, 255, 3606-3612.

Similä M, Kouki J, Martikainen P (2003) Saproxylic beetles in managed and seminatural Scots pine forests: quality of dead wood matters. Forest Ecology and Management, 174, 365381.

Solomon S, Intergovernmental Panel on Climate Change., Intergovernmental Panel on Climate Change. Working Group I. (2007) Climate Change 2007 : contribution of Working Group I to the Fourth Assessment Report of the Intergovernmental Panel on Climate Change. Cambridge University Press, Cambridge; New York, .

This article is protected by copyright. All rights reserved. 
Snover AK, Mantua NJ, Littell JS, Alexander MA, McClure M, Nye J (2013) Choosing and using climate-change scenarios for ecological-impact assessments and conservation. Conservation Biology, 27, 1147-1157.

Stokland JN (2001) The coarse woody debris profile: an archive of recent forest history and an important biodiversity indicator. Ecological Bulletins, 49, 71-83.

Stokland JN, Larsson K (2011) Legacies from natural forest dynamics: Different effects of forest management on wood-inhabiting fungi in pine and spruce forests. Forest Ecology and Management, 261, 1707-1721.

Stokland JN, Siitonen J, Jonsson BG (2012) Biodiversity in dead wood. Cambridge University Press.

Summers DM, Bryan BA, Crossman ND, Meyer WS (2012) Species vulnerability to climate change: impacts on spatial conservation priorities and species representation. Global Change Biology, 18, 2335-2348.

Thuiller W, Lavorel S, Araújo M (2005) Niche properties and geographical extent as predictors of species sensitivity to climate change. Global Ecology and Biogeography, 14, 347-357.

Thuiller W (2007) Biodiversity - Climate change and the ecologist. Nature, 448, 550-552.

Tikkanen O-P, Heinonen T, Kouki J, Matero J (2007) Habitat suitability models of saproxylic red-listed boreal forest species in long-term matrix management: Cost-effective measures for multi-species conservation. Biological Conservation, 140, 359-372.

This article is protected by copyright. All rights reserved. 
Tikkanen O-P, Martikainen P, Hyvärinen E, Junninen K, Kouki J (2006) Red-listed boreal forest species of Finland: associations with forest structure, tree species, and decaying wood. Annales Zoologici Fennici, 43, 373-383.

Tikkanen O-P, Matero J, Mönkkönen M, Juutinen A, Kouki, J (2012) To thin or not to thin bio-economic analysis of two alternative practices to increase amount of coarse woody debris in managed forests. European Journal of Forest Research, 131, 1411-1422.

Tikkanen O-P, Punttila P, Heikkilä R (2009) Species-area relationships of red-listed species in old boreal forests: a large scale data analysis. Diversity and Distributions, 15, 852-862.

Timonen J, Siitonen J, Gustafsson L, Kotiaho JS, Stokland JN, Sverdrup-Thygeson A, Mönkkönen M (2010). Woodland key habitats in northern Europe - concepts, inventory and protection. Scandinavian Journal of Forest Research, 25, 309-324.

Travis JMJ (2003) Climate change and habitat destruction: a deadly anthropogenic cocktail. Proceedings of the Royal Society B; 270, 467-473.

Tuomi M, Laiho R, Repo A, Liski J (2011) Wood decomposition model for boreal forests. Ecological Modelling, 222, 709-718.

Walther G, Berger S, Sykes M (2005) An ecological 'footprint' of climate change. Proceedings of the Royal Society B-Biological Sciences, 272, 1427-1432.

Walther G, Post E, Convey P et al. (2002) Ecological responses to recent climate change. Nature, 416, 389-395.

Watson JEM, Iwamura T, Butt N (2013) Mapping vulnerability and conservation adaptation strategies under climate change. Nature Climate Change, 3, 989-994.

This article is protected by copyright. All rights reserved. 
Wisz MS, Hjmans RJ, Li J, Townsend Peterson A, Graham CH, Guisan A, NCEAS Predicting Species Distribution Working Group (2008) Effects of sample size on the performance of species distribution models. Diversity and Distributions, 14, 763-773.

Yrjölä T (2002) Forest management guidelines and practices in Finland, Sweden and Norway. European Forest Institute Internal Report 11.

\section{Supporting Information}

Appendix S1 Litter in SIMA and calculation of the background litter.

Appendix S2. Checklist of threatened species and their habitat associations.

Appendix S3 Sub-priority functions used in the calculation of habitat suitability indexes.

Appendix S4 Limitations of the present landscape planning approach.

\section{Tables}

Table 1 Proportions of plots of the Finnish National Forest Inventory (total $\mathrm{N}=2,816$ ) included in each range of values for Stand Conservation Capacity (SCC) and Climate Vulnerability $(C V)$. For $C V$ the proportions are reported for each IPCC climate change scenario of increasing emissions (from B1 to A1B to A2).

\begin{tabular}{cccccc}
\hline SCC Range & $\%$ & CV Range & B1 & A1B & A2 \\
\hline $0.00-0.10$ & 11.6 & $-1.00-0.00$ & 8.9 & 1.2 & 1.8 \\
$>0.10-0.25$ & 16.7 & $>0.00-0.25$ & 63.0 & 9.2 & 20.3 \\
$>0.25-0.50$ & 44.7 & $>0.25-0.50$ & 26 & 62 & 68 \\
$>0.50-0.75$ & 24.4 & $>0.50-0.75$ & 2.1 & 24.7 & 9.5 \\
$>0.75-1.00$ & 2.5 & $>0.75-1.00$ & 0.2 & 2.7 & 0.9 \\
\hline
\end{tabular}

This article is protected by copyright. All rights reserved. 
Table 2 Summary statistics for each response category to climate change (according to the definition of Gillson) calculated for each vegetation zone (Zone) and in total under three IPCC climate change scenario of increasing emissions (from B1 to A1B to A2). We report the number of plots in the Finnish National Forest Inventory allocated in each category (N) and the means of the response for each category and zone.

\begin{tabular}{lccccccc}
\hline \multirow{2}{*}{ Category } & Zone & \multicolumn{2}{c}{ B1 } & \multicolumn{2}{c}{ A1B } & A2 \\
\cline { 3 - 8 } & Hemiboreal & 31 & 0.145 & 33 & 0.295 & 33 & 0.218 \\
& S boreal & 396 & 0.142 & 418 & 0.279 & 415 & 0.225 \\
Susceptible & C boreal & 205 & 0.135 & 223 & 0.256 & 222 & 0.213 \\
& N boreal & 64 & 0.168 & 70 & 0.332 & 69 & 0.263 \\
& Total & $\mathbf{6 9 6}$ & $\mathbf{0 . 1 4 2}$ & $\mathbf{7 4 4}$ & $\mathbf{0 . 2 7 8}$ & $\mathbf{7 3 9}$ & $\mathbf{0 . 2 2 5}$ \\
\hline \multirow{5}{*}{ Resilient } & Hemiboreal & 5 & 0.231 & 3 & 0.243 & 3 & 0.266 \\
& S boreal & 25 & 0.101 & 3 & 0.358 & 6 & 0.250 \\
& C boreal & 22 & 0.101 & 4 & 0.147 & 5 & 0.172 \\
& N boreal & 9 & 0.069 & 3 & 0.022 & 4 & 0.06 \\
& Total & $\mathbf{6 1}$ & $\mathbf{0 . 1 0 7}$ & $\mathbf{1 3}$ & $\mathbf{0 . 1 8 9}$ & $\mathbf{1 8}$ & $\mathbf{0 . 1 8 8}$ \\
\hline \multirow{5}{*}{ Resistant } & Hemiboreal & 4 & 0.031 & 1 & 0.041 & 1 & 0.072 \\
& S boreal & 61 & 0.032 & 3 & 0.015 & 9 & 0.027 \\
& C boreal & 80 & 0.029 & 7 & 0.036 & 8 & 0.032 \\
& N boreal & 44 & 0.045 & 11 & 0.026 & 14 & 0.033 \\
& Total & $\mathbf{1 8 9}$ & $\mathbf{0 . 0 3 4}$ & $\mathbf{2 2}$ & $\mathbf{0 . 0 2 8}$ & $\mathbf{3 2}$ & $\mathbf{0 . 0 3 2}$ \\
\hline \multirow{5}{*}{ Sensitive } & Hemiboreal & 64 & 0.070 & 67 & 0.134 & 67 & 0.105 \\
& S boreal & 828 & 0.067 & 886 & 0.135 & 880 & 0.105 \\
& C boreal & 646 & 0.055 & 719 & 0.120 & 718 & 0.094 \\
& N boreal & 332 & 0.048 & 365 & 0.087 & 362 & 0.071 \\
& Total & $\mathbf{1 8 7 0}$ & $\mathbf{0 . 0 6 0}$ & $\mathbf{2 0 3 7}$ & $\mathbf{0 . 1 2 1}$ & $\mathbf{2 0 2 7}$ & $\mathbf{0 . 0 9 5}$ \\
\hline
\end{tabular}

\section{Figure legends}

Fig. 1 Outlines of the SIMA model used in the simulation of the National Forest Inventory. The legend refers to the elements of the model. Picture modified from Kellomäki et al. (2008). $\mathrm{T}=$ Temperature, $\mathrm{P}=$ Precipitation.

This article is protected by copyright. All rights reserved. 
Fig. 2 Maps of Stand conservation Capacity $(S C C$, a) and Climate Vulnerability $(C V)$ for three IPCC climate change scenarios of increasing emissions (from B1 (b) to A1B (c)to A2 (d)) for the National Forest Inventory sample plots in Finland. The thresholds for separating $S C C$ and $C V$ categories were chosen using the Jenks natural breaks classification method. For $C V$ reference threshold values for $\mathrm{B} 1$ (b) are used for comparison with the other two scenarios. The borders of the four vegetation zones occurring in Finland are included in the maps. Box plots show the distribution of values (mean, interquartile range, outliers) of plots for $S C C$ and $C V$ for each vegetation zone (codes for zones: $\mathrm{Hb}=$ hemiboreal; $\mathrm{Sb}=$ Southern boreal; $\mathrm{Cb}=$ Central boreal; $\mathrm{Nb}=$ Northern boreal).

Fig. 3 Biplots for each IPCC climate change scenario of increasing emissions (from B1 to A1B to A2) categorizing the National Forest Inventory sample plots in Finland according to their values for Stand Conservation Capacity $(S C C)$ (y-axes) and Climate Vulnerability $(C V)$ (x-axes) with indicated the $\%$ of stands included in each response category to climate change, which are indicated in the small table with, in parentheses, the management actions suggested for the selected stands to halt the loss of biodiversity.

Fig. 4 Map of the values of the four response categories to climate change (susceptible, resilient, resistant, sensitive) across all the National Forest Inventory sample plots in Finland for three climatic scenarios of increasing emissions (from B1 to A1B to A2). Response values were separated in five classes (very low, low, intermediate, high, very high) whose thresholds were based on natural breaks (Jenks). For each response category the threshold values were the same across the three emission scenarios. Boundaries are drawn for the four Finnish vegetation zones.

This article is protected by copyright. All rights reserved. 

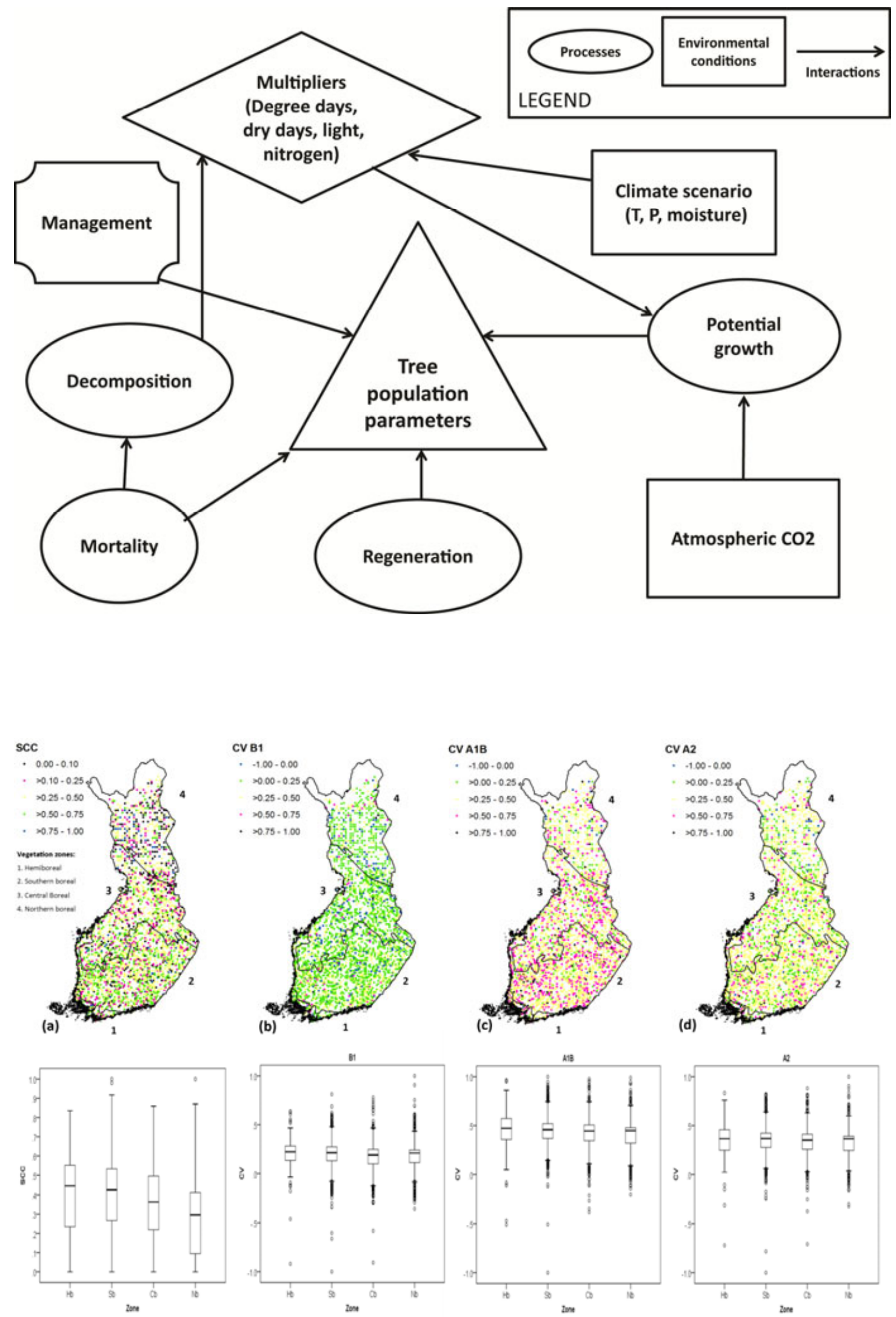

This article is protected by copyright. All rights reserved. 


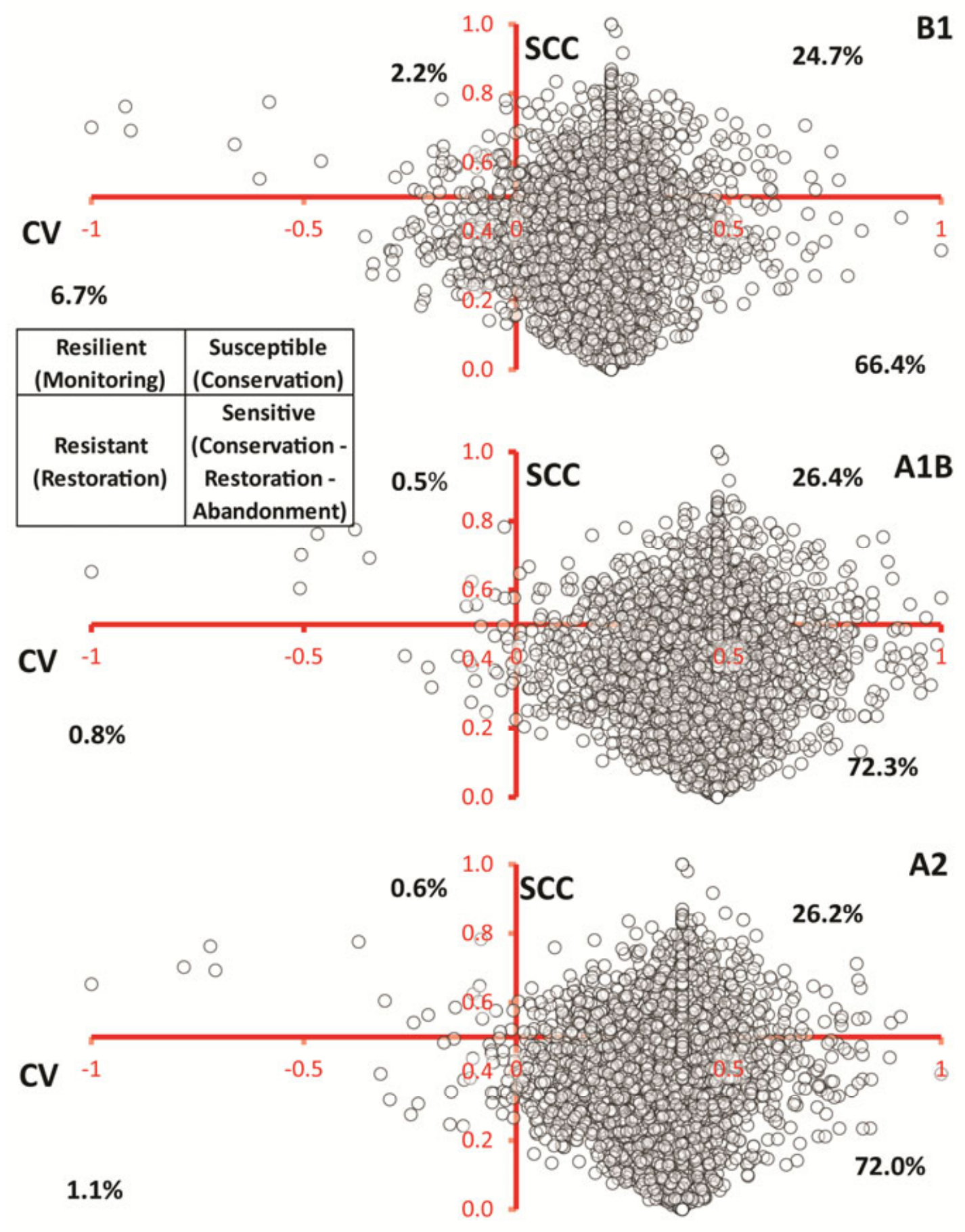

This article is protected by copyright. All rights reserved. 

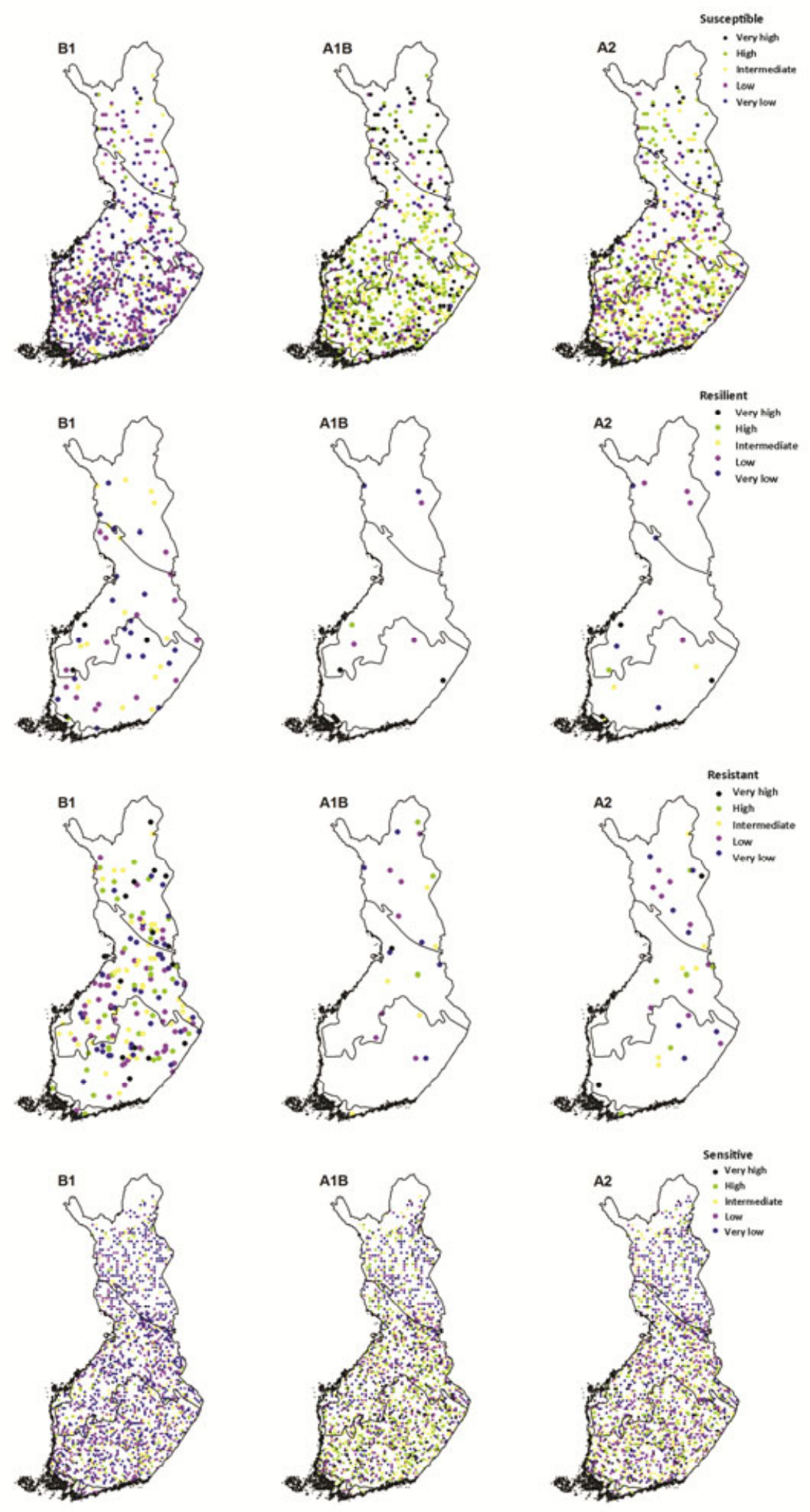

This article is protected by copyright. All rights reserved. 